\title{
ら旋状のワイヤによって補強されたゴム管 の断面に沿ら線荷重による変形特性
}

(平成 5 年11月 16 日 受理)

\author{
田中 博*1 $\cdot$ 赤坂 隆*2 $\cdot$ 加藤 満*3 $\cdot$ 加々美 茂*2
}

\begin{abstract}
要旨 高圧チューブは，ゴム層内に含まれるら旋状の鋼線によって強化されている．この複合ゴム層 は，鋼線方向とその直角方向に対して直交異方性弾性をもつ．以前にBreig ${ }^{1 \sim 3)}$ は，ら旋状に巻かれた鋼線の 変形特性について理論的並びに実験的研究を行っているが，ゴム層の影響については考察していない，本論 文では，鋼線とゴムの複合層一層から成る複合円筒のある断面の周縁に沿って一様な圧縮線荷重を与えたと きの変形について，ゴム複合体の理論4)を用いて解析した．波型の変形形状，および伸び，回転のカップリ ング変形に対する解析結果はそれぞれの実験結果とよく一致することが示される．ここで, 注意すべきは, 構成ゴム層が, 高圧チューブの波型変形形状の減衰性を高める効果をもつということである.
\end{abstract}

\section{1. 緒}

言

高圧チューブは，スチール線をコードとする一 方向強化ゴム層の積層構成になっていて, 各ュー ドはチューブの母線に対して平衡角 $\left( \pm 54.7^{\circ}\right)$ を 保つよらに巻かれている。このようなチューブが ある管断面に沿って一様な圧縮線荷重を受ける と，その位置を中心として減衰波的変形を生ずる ことが実験的に知られている(Fig. 1). Breig ${ }^{1) ~ 3) ~}$ はゴムを無視したスパイラル裸線の変形挙動につ いて理論解析と実験を行っている. しかし，この 波長並びに変形の及ぶ範囲，ならびにカップリン グ変形(伸縮，ねじれ)について、ゴムの影響を考 慮した解析的研究はなされていない。本研究で は, 強化繊維とゴムから成る一方向強化 FRR (Fiber Reinforced Rubber) 層に対する直交 異方性フック則4)を用い,チューブを異方性円筒 殼と見なして変形解析を行い, 波長やカップリン グ変形量に対する解析解を求めることを目的とし ている.ただし，ここでは，ら旋巻き単層のチュ

\footnotetext{
*1 ブリヂストンフローテック株式会社 （テ355 埼玉県東松山市新郷88-24）

*2 中央大学理工学部精密機械工学科 （テ112 東京都文京区春日1-13-27）

*3 武蔵工業大学工学部

（テ158 東京都世田谷区玉堤1-28-1）
}

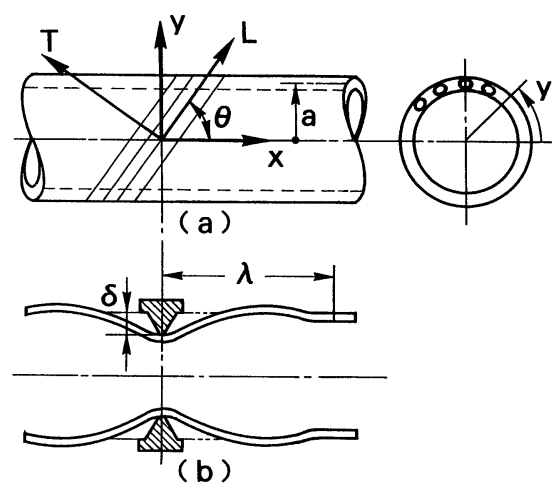

Fig. 1 (a) UDFRR tube coordinate systems,

(b) Axisymmetric deformation near clamped end

ーブについて解析する．この場合はバイアス積層 の場合に比べて, 強化繊維の比較的自由な変形挙 動が明確に捉えられるメリットがあるからであ る. また，この解析結果を検証するため， 2 種の 試験片について締め付け実験を行った。

\section{UDFRR の直交異方性}

ここで考学る高圧ゴムチューブは, 強化繊維が $x$ 軸方向に対して方位角 $\theta$ を以て巻かれた FRR の 1 層から成る円管とする。すなわち， SFRR (Spiral Fiber Reinforced Rubber) と考える. この円管壁は平面上に展開すれば，一方向繊維強 化ゴム (UDFRR : Unidirectional Fiber Reinforced 
Rubber)層となるから，その面内および面外フッ ク則はそれぞれ次のようにかける。

$$
\begin{aligned}
& \left\{\begin{array}{l}
N_{x} \\
N_{y} \\
N_{x y}
\end{array}\right\}=\left[\begin{array}{lll}
A_{x x} & A_{x y} & A_{x s} \\
A_{x y} & A_{y y} & A_{y s} \\
A_{x s} & A_{y s} & A_{s s}
\end{array}\right]\left\{\begin{array}{l}
\varepsilon_{x} \\
\varepsilon_{y} \\
\varepsilon_{x y}
\end{array}\right\} \\
& \left\{\begin{array}{l}
M_{x} \\
M_{y} \\
M_{x y}
\end{array}\right\}=\left[\begin{array}{lll}
D_{x x} & D_{x y} & D_{x s} \\
D_{x y} & D_{y y} & D_{y s} \\
D_{x s} & D_{y s} & D_{s s}
\end{array}\right]\left\{\begin{array}{l}
\kappa_{x} \\
\kappa_{y} \\
\kappa_{x y}
\end{array}\right\}
\end{aligned}
$$

ここで，面内ひずみ成分は变位関数 $u, v, w$ (Fig.

2）を用いて，次のように表される.

$$
\varepsilon_{x}=u_{, x}, \quad \varepsilon_{y}=v_{, y}+\frac{w}{a}, \quad \gamma_{x y}=u_{, y}+v_{, x}
$$

ただし，(,)記号は下添字についての微分を意味

するまた，曲率変化および㨝り率は

$$
\kappa_{x}=w_{, x x}, \quad \kappa_{y}=w_{, y y}, \quad \kappa_{x y}=2 w_{, x y}
$$

と表される。また，剛性マトリックス $\left[A_{i j}\right]$ およ び $\left[D_{i j}\right]$ の各要素は次のように与えられる4).

$$
\begin{aligned}
& A_{x x}=A_{L} \cos ^{4} \theta+A_{T} \\
& A_{x y}=A_{L} \sin ^{2} \theta \cos ^{2} \theta+\frac{1}{2} A_{T} \\
& A_{y y}=A_{L} \sin ^{4} \theta+A_{T} \\
& A_{s s}=A_{L} \sin ^{2} \theta \cos ^{2} \theta+\frac{1}{4} A_{T} \\
& A_{x s}=A_{L} \cos ^{3} \theta \sin \theta \\
& A_{y s}=A_{L} \sin ^{3} \theta \cos \theta \\
& D_{x x}=D_{L} \cos ^{4} \theta+D_{T} \\
& D_{x y}=D_{L} \sin ^{2} \theta \cos { }^{2} \theta+\frac{1}{2} D_{T} \\
& D_{y y}=D_{L} \sin ^{4} \theta+D_{T} \\
& D_{s s}=D_{L} \sin ^{2} \theta \cos { }^{2} \theta+\frac{1}{4} D_{T} \\
& D_{x s}=D_{L} \cos ^{3} \theta \sin \theta \\
& D_{y s}=D_{L} \sin ^{3} \theta \cos \theta
\end{aligned}
$$

ここで,

$$
\begin{aligned}
& A_{L}=E_{L} h, \quad A_{T}=E_{T} h \\
& D_{L}=\int_{-h / 2}^{h / 2} E_{L} \zeta^{2} d \zeta=\frac{h^{3}}{12} E_{L} \\
& D_{T}=\frac{h^{3}}{12} E_{T}
\end{aligned}
$$

である． $D_{L}, D_{T}$ の評価式は，繊維とゴムからな る複合材が肉厚方向に均質であるといら仮定に基 づくものである.

この評価式は実際の評価值に対して多少過大な値 を与える傾向がある.

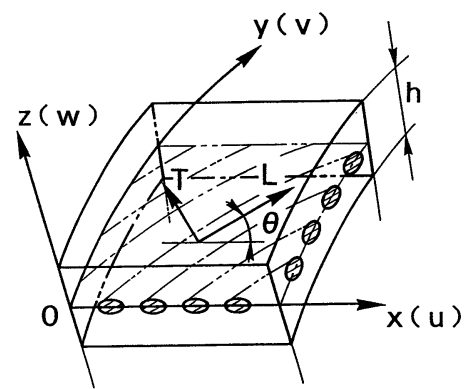

Fig. 2 Coordinate axes $x, y, z$ and $L, T$ set on the middle plane of the structural element of SFRR tube

\section{3. 円筒の釣合い方程式}

SFRR 円管の肉厚 $h$ は平均半径 $a$ に対して, 比 較的厚肉であるが，ここでは単純な $L . H$. Donnell ${ }^{5}$ 流の薄肉円筒殼理論になららこととす る. 膜力, せん断力および偶力の正の方向を Fig. 3 のように定義するとき，この構造要素の釣 合い条件式は次のように与えられる。

$$
\begin{aligned}
& \frac{\partial N_{x}}{\partial x}+\frac{\partial N_{x y}}{\partial y}=0, \quad \frac{\partial N_{x y}}{\partial x}+\frac{\partial N_{y}}{\partial y}=0 \\
& \frac{\partial Q_{x}}{\partial x}+\frac{\partial Q_{y}}{\partial y}+\frac{N_{y}}{a}=0 \\
& \frac{\partial M_{x}}{\partial x}+\frac{\partial M_{x y}}{\partial y}=Q_{x}, \\
& \frac{\partial M_{x y}}{\partial x}+\frac{\partial M_{y}}{\partial y}=Q_{y}
\end{aligned}
$$

式(10)を式(9)に代入して， $Q_{x}, Q_{y}$ を消去すると次式 を得る。

$$
\frac{\partial^{2} M_{x}}{\partial x^{2}}+2 \frac{\partial^{2} M_{x y}}{\partial x \partial y}+\frac{\partial^{2} M_{y}}{\partial y^{2}}+\frac{N_{y}}{a}=0
$$

式(8), (11)は変位系 $(u, v, w)$ に対して連立微分方 程式を与える。 ところで, 円筒の周方向に線状に 圧縮するときは，すべての膜力，モーメントは周 方向に一様になると考えられる．また同時に変位 系についても同様となるので，上式は著しく簡略 化される，すなわち, 変位系, 膜力およびモーメ ントは $x$ のみの関数となるので, 式(3), (8), (9)か ら次式が得られる。

$$
\begin{aligned}
& \varepsilon_{x}=\frac{d u}{d x}, \quad \varepsilon_{y}=\frac{w}{a}, \quad \gamma_{x y}=\frac{d v}{d x} \\
& \kappa_{x}=\frac{d^{2} w}{d x^{2}}, \quad \kappa_{y}=0, \quad \kappa_{x y}=0
\end{aligned}
$$




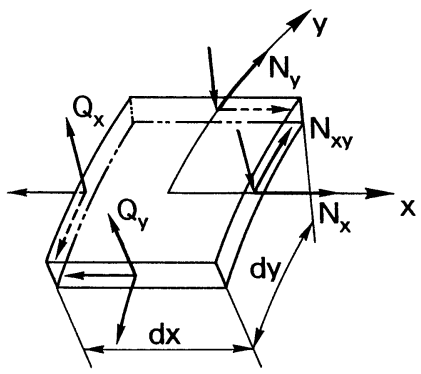

(a)

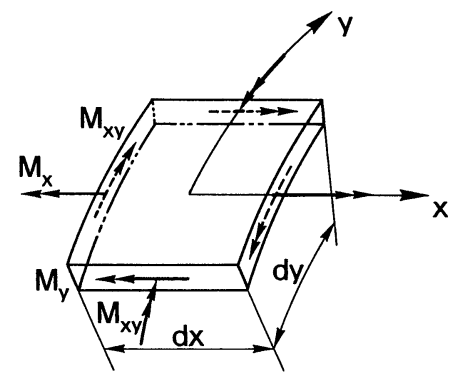

(b)

Fig. 3 (a) Membrane forces and transverse shearing forces,

(b) Bending and twisting moment of the structural element of SFRR tube

$$
\begin{aligned}
& \frac{d N_{x}}{d x}=0, \quad \frac{d N_{x y}}{d x}=0 \\
& \frac{d^{2} M_{x}}{d x^{2}}+\frac{N_{y}}{a}=0
\end{aligned}
$$

式(13)で，かしめ部をはなれた遠方で，もし何らの 拘束がなければ,

$$
N_{x}=N_{x y}=0
$$

としてよい.かくて，フック則：式(1)から

$$
\begin{aligned}
& A_{x x} \frac{d u}{d x}+A_{x y} \frac{w}{a}+A_{x s} \frac{d v}{d x}=0 \\
& A_{x s} \frac{d u}{d x}+A_{y s} \frac{w}{a}+A_{s s} \frac{d v}{d x}=0
\end{aligned}
$$

を得る。これを $d u / d x, d v / d x$ について解けば,

$$
\left[\begin{array}{ll}
A_{x x} & A_{x s} \\
A_{x s} & A_{s s}
\end{array}\right]\left(\begin{array}{l}
u_{, x} \\
v_{, x}
\end{array}\right)=-\frac{w}{a}\left(\begin{array}{l}
A_{x y} \\
A_{y s}
\end{array}\right)
$$

より

$$
\begin{aligned}
& u_{, x}=-\frac{w}{a} \frac{\left|\begin{array}{ll}
A_{x y} & A_{x s} \\
A_{y s} & A_{s s}
\end{array}\right|}{\left|\begin{array}{ll}
A_{x x} & A_{x s} \\
A_{x s} & A_{s s}
\end{array}\right|}=-\frac{w}{a} \frac{\overline{A_{x y}}}{\overline{A_{y y}}} \\
& v_{, x}=-\frac{w}{a} \frac{\left|\begin{array}{ll}
A_{x x} & A_{x y} \\
A_{x s} & A_{y s}
\end{array}\right|}{\left|\begin{array}{ll}
A_{x x} & A_{x s} \\
A_{x s} & A_{s s}
\end{array}\right|}=-\frac{w}{a} \frac{\overline{A_{y s}}}{\overline{A_{y y}}}
\end{aligned}
$$

と得られる。ここで,

$$
\begin{aligned}
\bar{A}_{x y}= & A_{x y} A_{s s}-A_{x s} A_{y s} \\
= & \left(A_{L} \sin ^{2} \theta \cos ^{2} \theta+\frac{1}{2} A_{T}\right) \\
& \times\left(A_{L} \sin ^{2} \theta \cos ^{2} \theta+\frac{1}{4} A_{T}\right)
\end{aligned}
$$

$$
\begin{aligned}
& -A_{L}^{2} \sin ^{4} \theta \cos ^{4} \theta \\
= & \frac{3}{4} A_{L} A_{T} \sin ^{2} \theta \cos ^{2} \theta+\frac{1}{8} A_{T}^{2} \\
\bar{A}_{y s}= & A_{x x} A_{y s}-A_{x y} A_{x s} \\
= & \left(A_{L} \cos ^{4} \theta+A_{T}\right) A_{L} \sin ^{3} \theta \cos \theta \\
& -\left(A_{L} \sin ^{2} \theta \cos ^{2} \theta+\frac{1}{2} A_{T}\right) \\
& \times A_{L} \cos ^{3} \theta \sin \theta \\
= & A_{L} A_{T} \sin \theta \cos \theta\left(\sin ^{2} \theta-\frac{1}{2} \cos ^{2} \theta\right) \\
\overline{A_{y y}}= & A_{x x} A_{s s}-A_{x s}^{2} \\
= & \left(A_{L} \cos ^{4} \theta+A_{T}\right)\left(A_{L} \sin ^{2} \theta \cos ^{2} \theta+\frac{1}{4} A_{T}\right) \\
& -A_{L}^{2} \cos ^{6} \theta \sin ^{2} \theta \\
= & A_{L} A_{T}\left(\sin ^{2} \theta \cos ^{2} \theta+\frac{1}{4} \cos ^{4} \theta\right)+\frac{1}{4} A_{T}^{2}
\end{aligned}
$$

である，よって，式(17)，(18)は，次のように表わさ れる。

$$
\begin{aligned}
& u_{, x}=-\frac{w}{a} \frac{3}{4} \frac{\sin ^{2} \theta}{\sin ^{2} \theta+\frac{1}{4} \cos ^{2} \theta} \\
& v_{, x}=-\frac{w}{a} \frac{\sin \theta\left(\sin ^{2} \theta-\frac{1}{2} \cos ^{2} \theta\right)}{\cos \theta\left(\sin ^{2} \theta+\frac{1}{4} \cos ^{2} \theta\right)}
\end{aligned}
$$

$u, v$ は，かくて，wが得られれば定められること になる。

\section{4. $w(x)$ の 決 定}

式(14)をフック則を用いて書き直すと次のように なる。 


$$
\begin{aligned}
M_{x} & =D_{x x} \frac{d^{2} w}{d x^{2}} \\
N_{y} & =A_{x y} u_{, x}+A_{y y} \frac{w}{a}+A_{y s} v_{, x} \\
& =A_{y y} \frac{w}{a}-\frac{w}{a} \frac{A_{x y} \overline{A_{x y}}+A_{y s} \bar{A}_{y s}}{\bar{A}_{y y}} \\
& =\frac{w}{a}\left(\frac{\bar{A}_{y y} A_{y y}-A_{x y} \bar{A}_{x y}-A_{y s} \bar{A}_{y s}}{\bar{A}_{y y}}\right) \\
& =\frac{w}{a} \frac{A}{\overline{A_{y y}}}
\end{aligned}
$$

ここで,

$$
\begin{aligned}
A= & \bar{A}_{y y} A_{y y}-A_{x y} \overline{A_{x y}}-A_{y s} \bar{A}_{y s} \\
= & \left\{A_{L} A_{T}\left(\sin ^{2} \theta \cos ^{2} \theta+\frac{1}{4} \cos ^{4} \theta\right)\right. \\
& \left.+\frac{1}{4} A_{T}^{2}\right\}\left(A_{L} \sin ^{4} \theta+A_{T}\right) \\
& -\left\{A_{L} A_{T}\left(\frac{3}{4} \sin ^{2} \theta \cos ^{2} \theta\right)+\frac{1}{8} A_{T}^{2}\right\} \\
& \times\left(A_{L} \sin ^{2} \theta \cos ^{2} \theta+\frac{1}{2} A_{T}\right) \\
& -\left\{A_{L} A_{T} \sin \theta \cos \theta\left(\sin ^{2} \theta-\frac{1}{2} \cos ^{2} \theta\right)\right\} \\
& \times\left(A_{L} \sin ^{3} \theta \cos \theta\right) \\
= & \frac{1}{4} A_{L} A_{T}^{2}+\frac{3}{16} A_{T}^{3}
\end{aligned}
$$

と書けるので,

$$
\frac{A}{\overline{A_{y y}}}=A_{T} \frac{1}{\cos ^{2} \theta\left(1+3 \sin ^{2} \theta\right)}
$$

となる.よって，式(14)は

$$
D_{x x} \frac{d^{4} w}{d x^{4}}+\frac{A}{\bar{A}_{y y}} \frac{w}{a^{2}}=0
$$

となる.ここで, $x$ の代わりに無次元座標 $\xi$ 導 入し,

$$
\xi=\frac{x}{a}, \quad 4 K^{4}=\frac{A a^{2}}{D_{x x} \overline{A_{y y}}}
$$

と拉けば，式(23)は次のように書き替えられる.

$$
\frac{d^{4} w}{d \xi^{4}}+4 K^{4} w=0
$$

この方程式の解は, 次のよらに減衰振動型になる.

$$
w=e^{-K \xi}\left(C_{1} \sin K \xi+C_{2} \cos K \xi\right)
$$

ここで, 減衰係数 $K$ は式(24)からゴム層の横剛性 $A_{T}$ に依存することがわかる。な拉, ゴム層がな い場合には $K$ はかなり小さい值となり，減衰し なくなる。

他方, 境界条件は， $\xi=0$ での変形の対称性から
次のように与えられる。
(1) $w=-\delta, \quad(\xi=0)$
(2) $w^{\prime}(\xi)=0, \quad(\xi=0)$

ここで, $\delta$ は線荷重による半径方向の強制変位量 である、式(27)から直ちに，

$$
C_{2}=-\delta
$$

を得る。また

$$
\begin{aligned}
w^{\prime}(\xi)= & e^{-K \xi} K\left\{-\left(C_{1}+C_{2}\right) \sin K \xi\right. \\
& \left.+\left(C_{1}-C_{2}\right) \cos K \xi\right\}
\end{aligned}
$$

を用いると，式(28)から

$$
C_{1}=C_{2}
$$

を得る.よって，

$$
C_{1}=C_{2}=-\delta
$$

と定められる. かくして，式(26)から

$$
\begin{aligned}
w & =-\delta e^{-K \xi}(\sin K \xi+\cos K \xi) \\
& =-\sqrt{2} \delta e^{-K \xi} \sin \left(K \xi+\frac{\pi}{4}\right)
\end{aligned}
$$

を得る．Fig. 4 に荷重点での強制変位によるたわ み波形を示した。このときの波長 $\lambda$ は，式(31)か ら次のように表される。

$$
\lambda=\frac{2 \pi a}{K}
$$

\section{5. カップリング変形}

荷重点での半径方向強制変位によって, SFRR 円管には軸方向伸びと軸まわりの回転が起こる. すなわち, カップリング変位 $u$ および $v$ である. 式(17)，(18)から，u，vはそれぞれ次のように求めら れる。

$$
u=-\frac{\bar{A}_{x y}}{\bar{A}_{y y}} \int_{0}^{\xi} w d \xi=\frac{\bar{A}_{x y}}{\bar{A}_{y y}} \frac{\delta}{K}\left(1-e^{-K \xi} \cos K \xi\right)
$$

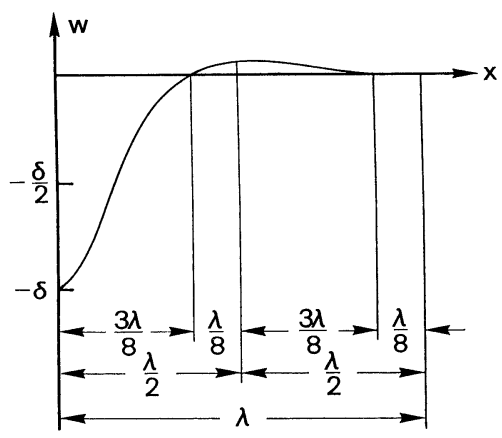

Fig. 4 Wavy deflection pattern in the vicinity of line loading 


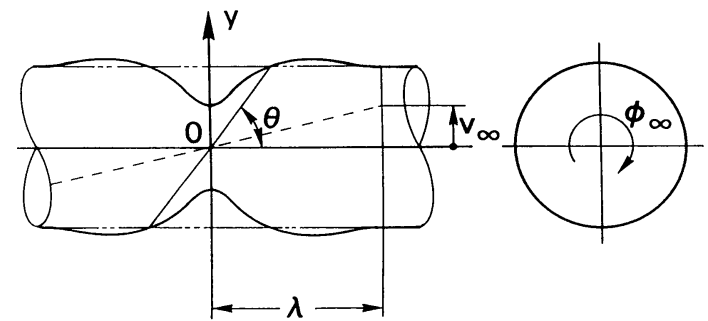

Fig. 5 Coupled rotation angle, $\phi_{\infty}$

同様にして

$$
v=\frac{\overline{A_{y s}}}{\overline{A_{y y}}} \frac{\delta}{K}\left(1-e^{-K \xi} \cos K \xi\right)
$$

式(33)は，くびれ $\delta$ にって軸方向に(無限遠点 で)一定量 $u_{\infty}$

$$
u_{\infty}=\frac{3}{4} \frac{\sin ^{2} \theta}{\sin ^{2} \theta+\frac{1}{4} \cos ^{2} \theta} \frac{\delta}{K}
$$

だけ伸びることを意味する。また式(34)は，周方向 に(無限遠点で) 一定量 $v_{\infty}$ :

$$
v_{\infty}=\frac{\sin \theta\left(\sin ^{2} \theta-\frac{1}{2} \cos ^{2} \theta\right)}{\cos \theta\left(\sin ^{2} \theta+\frac{1}{4} \cos ^{2} \theta\right)} \frac{\delta}{K}
$$

だけ移動する。すなわち，回転角 $\phi_{\infty}$ を生ずるこ とを意味する (Fig. 5).

$$
\phi_{\infty}=\frac{v_{\infty}}{a}=\frac{\sin \theta\left(\sin ^{2} \theta-\frac{1}{2} \cos ^{2} \theta\right)}{\cos \theta\left(\sin ^{2} \theta+\frac{1}{4} \cos ^{2} \theta\right)} \frac{\delta}{K a}
$$

ただし，

$$
\begin{aligned}
\frac{\overline{A_{y s}}}{\overline{A_{y y}}}=\frac{\sin \theta\left(\sin ^{2} \theta-\frac{1}{2} \cos ^{2} \theta\right)}{\cos \theta\left(\sin ^{2} \theta+\frac{1}{4} \cos ^{2} \theta\right)} \\
=\frac{\tan \theta\left(\tan ^{2} \theta-\frac{1}{2}\right)}{\tan ^{2} \theta+\frac{1}{4}}
\end{aligned}
$$

と得られるので,

$$
\tan ^{2} \theta=\frac{1}{2}, \quad \theta=35.26^{\circ}
$$

では, $\phi_{\infty}=v_{\infty}=0$ となり, カップリング回転は

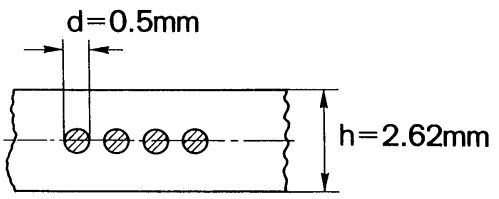

Fig. 6 Dimensions of SFRR cross section

\section{6. 数 值 計 算}

Fig. 6 にSFRR 円管壁断面の構成と寸法を示 した. 数值計算に必要な寸法諸元および材料特性 を以下に与える。

$$
\begin{aligned}
& d=0.50 \mathrm{~mm}, \quad a=11.79 \mathrm{~mm} \\
& h=2.62 \mathrm{~mm}, \quad p=57.2 \mathrm{~mm} \\
& \tan \theta=\frac{2 \pi a}{p}=1.30 \\
& \theta=\tan ^{-1}(1.30) \times \frac{180}{\pi}=52.33^{\circ} \\
& n_{f}=1 \text { 本 } / \mathrm{mm}, \quad E_{f}=210 \mathrm{GPa}, \quad E_{m}=5 \mathrm{MPa} \\
& V_{f}=\pi d^{2} n_{f} /(4 h)=0.075 \\
& V_{m}=1-V_{f}=0.925 \\
& E_{T}=\frac{4}{3} \frac{E_{m}}{V_{m}}=7.21 \mathrm{MPa} \\
& A_{T}=E_{T} h=1.888 \times 10^{4} \mathrm{~N} / \mathrm{m} \\
& D_{L}=E_{f} \frac{\pi d^{4}}{64} n_{f}+E_{m} \frac{h^{3}}{12} V_{m} \\
& =6.512 \times 10^{-1}(\mathrm{~N} \cdot \mathrm{m})
\end{aligned}
$$

$D_{L}$ は式(7)によらず，上記のような評価を行った のは，より正確な值を得るためである． $D_{T}$ は $D_{L}$ に比べて小さいので省略する.すなわち $D_{x x} \doteq D_{L}$ $\cos ^{4} \theta$ とする.

(1)波 長 $\lambda$

式(24)から

$$
\begin{aligned}
K & =\left(\frac{a^{2} A}{4 D_{x x} \overline{A_{y y}}}\right)^{1 / 4}=\left(\frac{a^{2} A_{T}}{4 D_{L} \cos ^{6} \theta\left(1+3 \sin ^{2} \theta\right)}\right)^{1 / 4} \\
& =(6.715)^{1 / 4}=1.610 \\
\lambda & =\frac{2 \pi a}{K}=46.02 \mathrm{~mm}
\end{aligned}
$$

と求められる.

(2)カップリング変位 $u_{\infty}$

式(35)から

$$
\frac{u_{\infty}}{\delta}=\frac{\bar{A}_{x y}}{\overline{A_{y y}}} \frac{1}{K}=\frac{1}{K} \frac{3}{4+\cot ^{2} \theta}=0.4055
$$




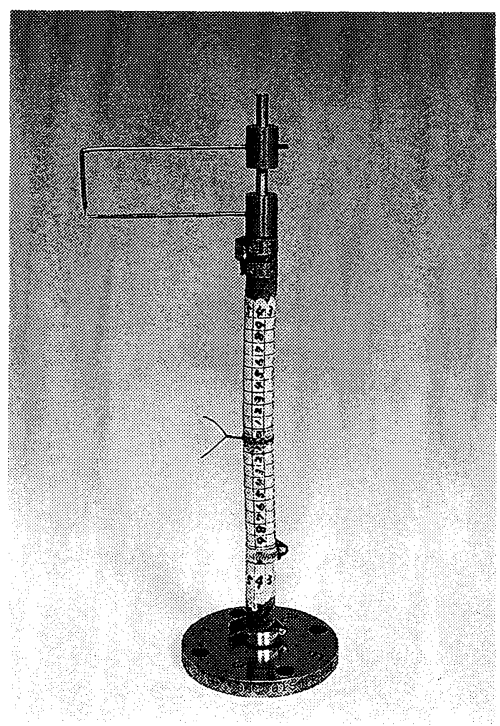

Fig. 7 Test apparatus

と得られる.

(3)カップリング回転 $\phi_{\infty}$

式(37)から

$$
\begin{aligned}
\frac{\phi_{\infty}}{\delta} & =\frac{1}{K a} \frac{\overline{A_{y s}}}{\bar{A}_{y y}}=\frac{1}{K a} \frac{\tan \theta\left(\tan ^{2} \theta-\frac{1}{2}\right)}{\tan ^{2} \theta+\frac{1}{4}} \\
& =0.0417
\end{aligned}
$$

と求められる.

\section{7. 実験と考察}

実験は, 前節の数值例の寸法・特性と同じ試験 片について実施した。 その一端を完全に固定し， 他端は, 軸方向の移動と, 軸心まわりの回転を, 自由にした試験片を用いて，その中央部を細いワ イヤでしばることで，一様な半径方向の収縮を与 えた(Fig. 7)。収縮量は, 3 水準とした。試験片 は, 内側の厚いゴムの層に, 軸心方向に多数の切 込みを入れたもの(1)と，そうでないもの(2)の，2 種類を用いた。 以下の図で, 試験片 1, 2 の測定

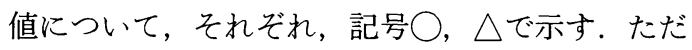
し, 試験片は, 軸線方向には, 中央部から両端に 向けて，10 $\mathrm{mm}$ の, 円周方向には，8 等分，つま

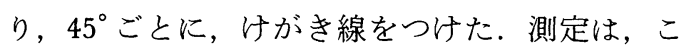

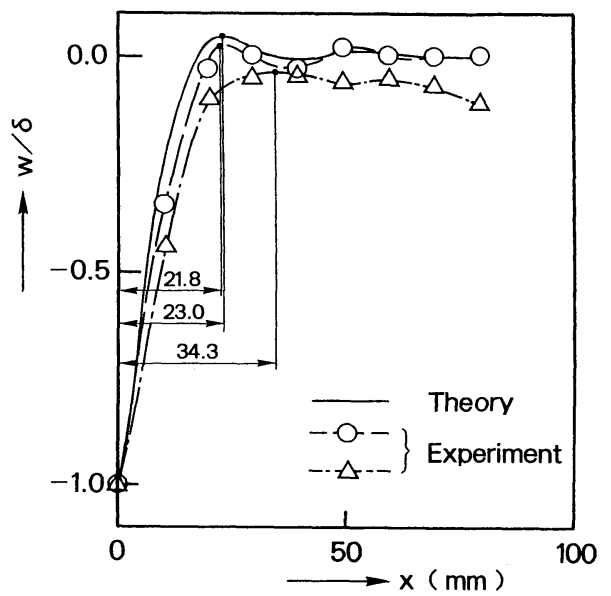

Fig. 8 Radial displacement distribution

れらのけがき線について行った。な拈，以下の図 で, 実線は理論值を, 破線, 一点鎖線は, それぞ れ, 試験片 1,2 に対する測定值の近似曲線を表 わす。

\section{(1) 波状変形}

圧縮力による半径方向の変位は, 中央部を挟ん で，対称に位置する点での測定值を平均化した。 さらに，それら点での平均化した測定值を中央部 での強制変位量で, 割って無地元化した. Fig. 8 に, 半径方向の変位分布を示した. 図中に記した 23.0,21.8，34.3はそれぞれ理論值, 試験片 1, 試 験片 2 が第 1 のピーク值を持つ位置を表わしてい る.この図から, 実験值と理論値は, よく一致す ることがわかる。しかし, 詳細にみれば, 試験片 $1(\bigcirc)$ は, 荷重点から離れるにしたがって, その 内側ゴム層につけた切り込及のため, 減衰効果が なく, 振動傾向にあり, 逆に, 試験片 $2(\triangle)$ は, 荷重点からはなれても, なおわずかな半径方向の 一定の収縮をしめす過減衰傾向にあることがわか る.これは, 内側ゴムの影響を示すものと解釈で きる. 実験值 $\lambda_{\exp }$ は，それぞれ， $\lambda_{1}=40.5 \mathrm{~mm}$, $\lambda_{2}=50.0 \mathrm{~mm}$ と得られる.ここで, 理論式の仮 定が二つの試験片の中間的性状となっているの で, 実験的に得られる波長 $\lambda_{\exp }$ は $\lambda_{\exp }=\left(\lambda_{1}+\lambda_{2}\right)$ $/ 2=45.25 \mathrm{~mm}$ と求められ, 理論的な波長 $\lambda_{\text {theo }}$ $=46.02$ に近い值を取ることが確かめられた。な お。, Breig) ${ }^{3)}$, 荷重点から軸方向にワイヤ径の50 倍の距離,つまり, この試験片の場合, 0.50 $\mathrm{mm} \times 50=25 \mathrm{~mm}$ を影響範囲と見積ればよいとし 


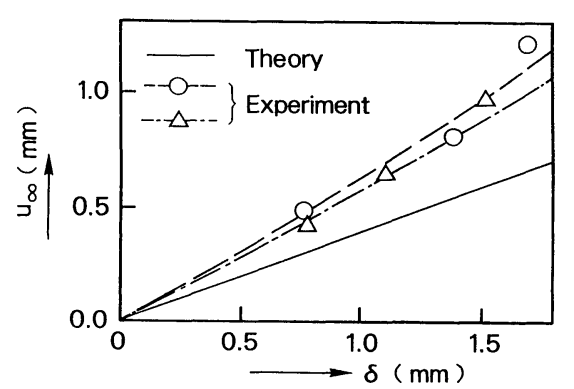

Fig. 9 Axial displacement

ている.この影響長さは, 同時にら旋の編上げピ ッチ $p=57.2 \mathrm{~mm}$ の約半分の長さに相当する.

\section{(2) 軸方向の伸び}

Fig. 9 に, 半径方向の強制変位量 $\delta$ にたいす る，軸方向の変位 $u_{\infty}$ を示した．この図から，実 験値と理論值は，実験値のばらつき等を考慮する と，ほぼよい傾向的一致が得られた。 また，この 図でも, 試験片 1,2 の順に, 值が小さくなるの は, 内側ゴム層での切り込みの有無による剛性の 違いのためと推定できる.

\section{（3）軸心まわりの回転}

Fig. 10に, 半径方向の強制変位量 $\boldsymbol{\delta}$ に対する, 軸心まわりの回転量 $\phi_{\infty}$ を示した。 この場合も， 実験值と理論值は，実験值のばらつきを考えると ほぼよい一致を示すことがわかった。また，この 図でも，試験片 1,2 の順に，值が小さくなるの は，前記の理由による，剛性の違いのためと推定 できる.

\section{8. 結 論}

FRR ら旋巻き単層の高圧チューブの断面に沿 万圧縮線荷重によるくびれ量 $\boldsymbol{\delta}$ に対する波状変 形について解析し, 以下の結論を得た.

1）波長 $\lambda$ についての表式を与えた。この値は 実測值とよく一致する。 $\lambda$ はゴムの剛性およびス

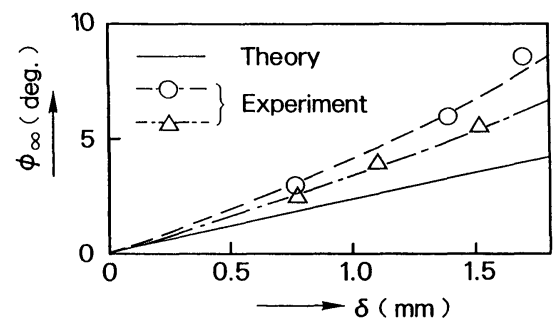

Fig. 10 Tube rotation angle as a function of forced displacement

チールコードの曲げ剛性に比例する傾向がある.

2） Fig. 8 の結果から波状変形の減衰性が顕著と なっているが，これはゴムの剛性がかなり影響す るためと思われる。

3）〈びれ量 $\boldsymbol{\delta}$ に対して SFRRチューブは軸方 向に伸びる，その量 $u_{\infty}$ は簡単な表式(35)で与えら れ，実測値と定性的には注ぼよい致を示す。

4）くびれ量 $\delta$ に対して SFRR チューブの断面 は捩れる。年の回転量 $\phi_{\infty}$ は表式(37)によって与え られ，これも実測值とほぼよい一致を示す。

5）この変形解析法は, 多層積層 SFRR チュブに対しても容易に拡張できる。

〔附 記]本論文は，第 7 回エラストマー討論会 (平成 5 年12月 9 日 於神田・学士会館)にて発表 したものである。

\section{参 考 文 献}

1) W. F. Breig,: SAE Technical Paper No. 881301, 1988, pp. 41-55

2) W. F. Breig,: SAE Technical Paper No. 891920, 1989, pp. 91-105

3) W. F. Breig,: SAE Technical Paper No. 901656, 1990, pp. 1-7

4) T. Akasaka,: "'Flexible Composites", Chapt. 9 of ''Textile Structural Composites.' ed. by T. W. Chou and F. K. Ko, Elsevier, 1989, pp. 279-330

5) L. H. Donnell,: NACA TR. No. 479, 1933 


\title{
DEFORMATION CHARACTERISTICS OF SPIRAL-WIRE REIN- FORCED RUBBER TUBE UNDER LINE LOAD ALONG A CROSS SECTION
}

\author{
Hiroshi TANAKA (Bridegestone Flowtech Co., 88-24 Shingo, Higashimatuyama-shi, \\ Saitama 355, Japan), Takashi AKASAKA, Shigeru KAGAMI (Department of Preci- \\ sion Mechanics, Faculty of Science and Engineering, Chuo University, 1-13-27 \\ Kasuga, Bunkyo-ku, Tokyo 112, Japan), and Mitsuru KATOH (Faculty. of Eng., \\ Musashi Institute of Technology, 1-28-1, Tamazutsumi, Sotagaya-ku, Tokyo 158, \\ Japan)
}

The high pressure tube is usually reinforced by spirally wound steel wires embedded in rubber layers. This composite rubber layer has an orthotropic elasticity with respect to the wire direction together with the transverse direction. Previously, Breig ${ }^{1) \sim 3)}$ studied chracteristic deformation of spiral wires theoretically and experimentally, however, did not consider the effect of rubber layer. In this paper, we analyzed the deformation properties of a one-ply composite tube subjected to the compressive line load uniformly distributed along a cross section periphery, by using the elastomer composite therory ${ }^{4)}$. The predicted results for the deformation with a wavy pattern and for the coupled elongation and rotation due to the line load are proved to agree well the corresponding experimental results. It should be noted that the elasticity of a constituent rubber layer gives a marked damping effect on the characteristic wave pattern of such a loaded pressure tube.

(Received on November 16, 1993) 